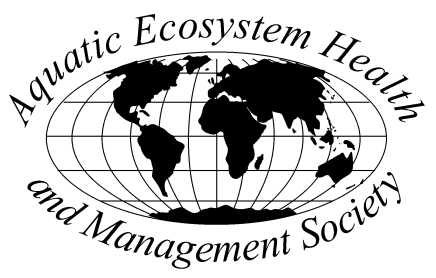

\title{
Effects of petroleum and its derivatives in benthic communities at Baía de Todos os Santos/Todos os Santos Bay, Bahia, Brazil
}

\author{
M.C. Peso-Aguiar*, D.H. Smith, R.C.F. Assis, L.M. Santa-Isabel, S. Peixinho, \\ E.P. Gouveia, T.C.A. Almeida, W.S. Andrade, C.R.G. Carqueija, F. Kelmo, \\ G. Carrozzo, C.V. Rodrigues, G.C. Carvalho, A.C.S. Jesus
}

Departamento de Zoologia, Instituto de Biologia, Universidade Federal da Bahia, Campus Universitário de Ondina s/n CEP 401170-210, Salvador, Bahia, Brazil

\begin{abstract}
Benthic community structure and diversity have been investigated to assess stress conditions of Todos os Santos Bay, Bahia, Brazil, as a possible result of the extraction, transportation and refining of petroleum, activities carried out in this area for more than 40 years. Samples were collected over two years, at four stations under the direct influence of stress-causing activities and at a control station. Benthic indices were calculated for all intertidal communities. The density, relative abundance, frequency of occurrence, diversity, similarity and occurrence of preferential species were recorded. Linear correlation indices were calculated to establish comparisons between ecological parameters of the studied communities and concentrations of heavy metals, hydrocarbons, petroleum pollution indicators and sediment mud percentages. The polychaete worms were the dominant group - up to $92 \%$ dominance in the community within the influence of refinery activities. Diversity indices indicated significant stress related spatial gradients tied to petroleum. The refinery sample station showed notable differences in its biodiversity figures compared to the other stations. Quantitative benthic indices showed negative correlations between the presence of cadmium, hydrocarbons, $n$-alkanes and the unresolved complex mixture in the intertidal zone marine sediments. (C) 2000 Elsevier Science Ltd and AEHMS. All rights reserved.
\end{abstract}

Keywords: Benthos; Benthic index; Diversity; Hydrocarbons; Heavy metals

\section{Introduction}

Due to their relatively restricted mobility, benthic communities cannot avoid potentially harmful environmental conditions, whether temporary or permanent. In coastal areas, such organisms are frequently associated with pelagic food chains and as a result, constitute important links in the transport of contaminants to higher trophic levels of the food chain,

\footnotetext{
* Corresponding author. Tel.: +55-71-247-3744; fax: +55-71245-6909.

E-mail address: mpeso@e-net.com.br (M.C. Peso-Aguiar).
}

including fish and eventually human beings (Smith et al., 1987).

Petroleum has been identified, in various parts of the world, as one of the most serious contaminants of the oceans. Its various component parts interact with biota at different levels of biological organisation creating possible adverse effects. Potential causal factors produce qualitative and quantitative changes in the community structure determined by a series of spatial and temporal variables to which species react differently (Goldberg, 1972; Warwick and Clarke, 1991).

On the Bahian Coast, the environmental impact of 


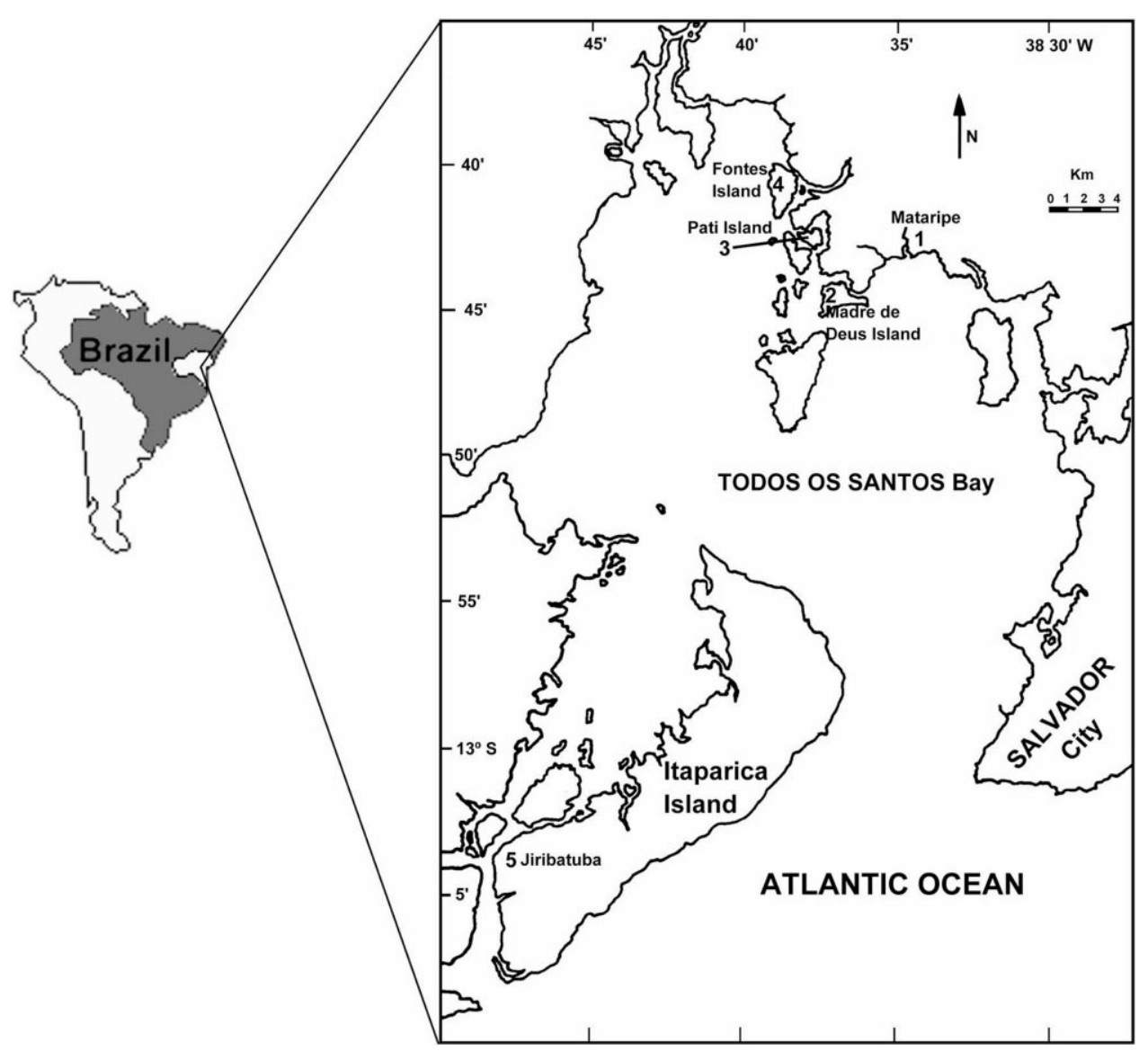

Fig. 1. Location of the sampling stations in the Todos os Santos Bay, Bahia, Brazil.

petroleum hydrocarbons is at its most critical point in the Todos os Santos Bay. The discovery and development of oil wells, started in the 1940s, and the subsequent construction of a large oil refinery and a maritime terminal have enhanced the problem of petroleum based contaminants. In view of these local environmental conditions, this study aims to characterise the spatial gradient of effects established by oil extraction in the Todos os Santos Bay through the assessment of the distribution of benthic indicators in zoobenthic communities in sample areas spatially distributed according to the type of petroleum based activity.

\section{Materials and methods}

Samples were taken from five stations located in the
Bay of Todos os Santos mangroves (Fig. 1) - Station 1, Mataripe $\left(12^{\circ} 42^{\prime} 06^{\prime \prime} \mathrm{S}\right.$; $\left.38^{\circ} 34^{\prime} 39^{\prime \prime} \mathrm{W}\right)$; Station 2, Madre de Deus Island $\left(12^{\circ} 43^{\prime} 54^{\prime \prime} \mathrm{S} ; 38^{\circ} 37^{\prime} 15^{\prime \prime} \mathrm{W}\right)$; Station 3, Pati Island $\left(12^{\circ} 42^{\prime} 30^{\prime \prime} \mathrm{S} ; 38^{\circ} 37^{\prime} 30^{\prime \prime} \mathrm{W}\right)$; Station 4, Fontes Island $\left(12^{\circ} 49^{\prime} 48^{\prime \prime} \mathrm{S} ; 38^{\circ} 38^{\prime} 54^{\prime \prime} \mathrm{W}\right)$; Station 5, Jiribatuba (control; $13^{\circ} 03^{\prime} 25^{\prime \prime} \mathrm{S}$; $38^{\circ} 47^{\prime} 38^{\prime \prime} \mathrm{W}$ ).

The location of the stations in the influence area of Petróleo do Brasil, SA (PETROBRAS) was aimed at the specific characterisation of impacts related to the oil refining process (Station 1), the transport of petroleum and its derivatives (Stations 2 and 3) and finally the process of extraction from underwater wells (Station 4). Samples were collected quarterly, between February 1994 and December 1995, in a total of eight sampling campaigns.

The meso-littoral region of the Todos os Santos 
Bay mangroves consists of unconsolidated sediments forming wide coastal areas with broad low slopes. The resulting large extensions of uncovered shore at low tide were divided into three strips or zones to attain clear representation of the macrozoobenthic communities present in each of the fauna distribution areas - Upper Meso-littoral (UM), the zone between the beginning of the supra-littoral area to the end of the meso-littoral area that is covered by mangrove vegetation; Middle Meso-littoral (MM), the intermediate strip between the end of UM and half of the shore area left uncovered at low-tide and Lower Meso-littoral (LM), the zone between the waterline and MM.

For each campaign, quantitative samples were obtained from the substratum of 10 areas of $30 \times 30 \mathrm{~cm}^{2}$, laid out at random and dug to a depth of $20 \mathrm{~cm}$, comprising areas of $0.9 \mathrm{~m}^{2}$ per meso-littoral zone and $2.7 \mathrm{~m}^{2}$ of total sample area per station. A rough sieving was completed in the field by washing the collected material through a series of overlaid sieves, with mesh sizes of 1,2 and $5 \mathrm{~mm}$, respectively. The polychaetes found were anaesthetised in the field, using a $7.5 \%$ magnesium chloride solution and then preserved in a $4 \%$ formaldehyde solution.

Qualitative investigations were also carried out through the occasional capture of specimens in each meso-littoral zone sampled. The different morphotypes obtained in the qualitative and quantitative samples were counted and preserved in $4 \%$ formaldehyde solution or in $70 \%$ alcohol as specifically required. The identification of the organisms was based on technical species identification literature and comparisons with the species collection that currently forms the reference base for the Zoology Department of the Universidade Federal da Bahia.

The parameters estimated for the zoobenthic communities were as follows: density (individuals per $\mathrm{m}^{2}$ ), relative abundance, frequency, three diversity indices, the Shannon-Weiner diversity index, Margalef's species richness, and Simpson's number of abundant species index $(1 /$ “ $C$ " simpson $)$ and finally similarity indices, Gower's Quantitative index $(S G)$ and Jaccard's Qualitative index $(S J)$ (Digby and Kempton, 1987). The categories of the relative abundance scale, as defined by Peixinho and Peso-Aguiar (1989), were as follows: 'very abundant' (1.00-0.61), 'abundant' (0.60-0.31), 'numerous' (0.30-0.11), 'slightly numerous' (0.10-0.02), 'scarce' $(0.01-0.05)$ and 'rare' $(<0.05)$. Cluster analysis was based on the Unweighted Pair Group Method using Arithmetic Means (UPGMA) algorithm (Sneath and Sokal, 1973). Variables were compared using the ANOVA non-parametric variance analysis developed by Friedman (1937) and modified and described by Conover (1971). A further classification of the fauna was completed with Two-Way Indicator Species Analysis (TWINSPAN; Hill, 1979). Lastly, Pearson's linear correlation coefficient $(r)(\alpha=0.05)$ was calculated to establish correlations between ecological parameters of the communities under study and concentrations of heavy metals $(\mathrm{Cd}, \mathrm{Pb}, \mathrm{Cu}, \mathrm{Mn}, \mathrm{Cr}$, As), hydrocarbons (n-alkanes, PAHs), and sediment mud percentages analysed by Tavares (1996), indicators of pollution by petroleum (Unresolved Complex Mixture (UCM); Carbon Preferential Index (CPI)).

\section{Results and discussion}

The number of individual organisms quantitatively captured totalled 24,199. Of these, 3112 were collected at Station 1, 7677 at Station 2, 5610 at Station 3, 3226 at Station 4, and 4574 individuals at Station 5 (control). These organisms represented 333 different species of benthic invertebrates captured during two years of sampling. Densities measured quarterly over two years revealed irregular seasonal fluctuations, since only station 1 repeated the density cycle registered in the first year, where it was observed that spring was the period in which the populations reached their highest numbers per square meter. At the other stations, peak densities occurred at different points from one year to the next (Fig. 2).

Eight major taxonomic groups of marine invertebrates were represented in the samples. Only Annelida (Polychaeta), Mollusca, and Crustacea were present at all times at all the sampling stations. A gradient of decreasing densities in the sampling stations was as follows: $2>3>5>4>1$; however, the stations within the area of influence of PETROBRAS did not differ significantly in relation to the control station. Polychaete worms dominated the other benthic groups at all the stations (Table 1 and Fig. 3), while the mollusc and crustacean communities present in the samples showed varied percentages ranging from 


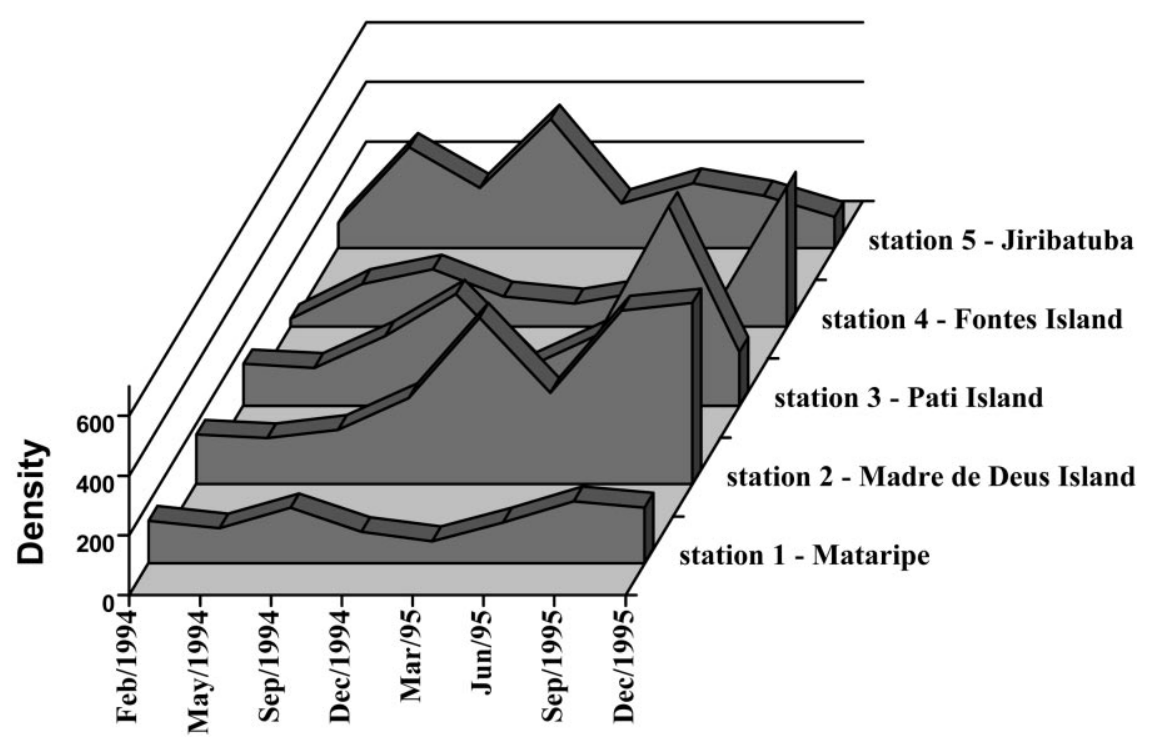

Fig. 2. Temporal distribution of density (individuals per $\mathrm{m}^{2}$ ) of the benthic communities at the sampling stations (February 1994-December 1995).

Table 1

Density $\left(D\right.$, individuals per $\mathrm{m}^{2}$ ), relative abundance $(\mathrm{Ab})$ and frequency $(\mathrm{Fr})$ of the zoobenthic groups at the sampling stations, February $1994-$ December 1995

\begin{tabular}{|c|c|c|c|c|c|c|c|c|c|c|c|}
\hline \multirow[t]{3}{*}{ Taxonomic groups } & \multicolumn{10}{|c|}{ Sampling stations } & \multirow[t]{3}{*}{ Fr $\%$} \\
\hline & \multicolumn{2}{|l|}{1} & \multicolumn{2}{|l|}{2} & \multicolumn{2}{|l|}{3} & \multicolumn{2}{|l|}{4} & \multicolumn{2}{|l|}{5} & \\
\hline & $D$ & $\mathrm{Ab}$ & $D$ & $\mathrm{Ab}$ & $D$ & $\mathrm{Ab}$ & $D$ & $\mathrm{Ab}$ & $D$ & $\mathrm{Ab}$ & \\
\hline Nematoda & 0 & - & 0 & - & 0 & - & 0.1 & 0.0007 & 0 & - & 20 \\
\hline Nemertini & 0.1 & 0.001 & 0.1 & 0.0003 & 0.1 & 0.0004 & 0 & - & 0.1 & 0.0005 & 80 \\
\hline Annelida (Polychaeta) & 132.1 & 0.92 & 202.6 & 0.57 & 143.5 & 0.55 & 78.2 & 0.52 & 115.4 & 0.54 & 100 \\
\hline Mollusca & 1.6 & 0.01 & 79.4 & 0.22 & 80.9 & 0.31 & 56.2 & 0.38 & 83.3 & 0.39 & 100 \\
\hline Arthropoda (Crustacea) & 10.3 & 0.07 & 72.4 & 0.20 & 34.6 & 0.13 & 14.1 & 0.09 & 12.4 & 0.06 & 100 \\
\hline Sipuncula & 0 & - & 0.1 & 0.0003 & 0.1 & 0.0004 & 0 & - & 0.1 & 0.0005 & 60 \\
\hline Echinodermata & 0 & - & 0.5 & 0.001 & 0.5 & 0.002 & 0.5 & 0.003 & 0.5 & 0.002 & 80 \\
\hline \multirow[t]{2}{*}{ Chordata (Cephalochordata) } & 0 & - & 0.5 & 0.001 & 0 & - & 0.1 & 0.0007 & 0.1 & 0.0005 & 60 \\
\hline & 144.1 & 1.00 & 355.4 & 1.00 & 259.7 & 1.00 & 149.4 & 1.00 & 211.8 & 1.00 & - \\
\hline
\end{tabular}

abundant to scarce. All other groups were classified as rare.

The TWINSPAN (Hill, 1979) statistical program was used to separate organisms in decreasing order of occurrence and as such, to identify so-called 'preferential species'. Only species with more than $70 \%$ occurrence are included in this first level of classification. Seventeen species were selected repre- senting the following phyla: Porifera (5), Annelida (Polychaeta) (8) and Mollusca (5) (Table 2).

The phylum Porifera was represented by five species, three of which (Laxosuberites spp. 1 and 2 and Halichondria sp.) occurred exclusively at Station 1 and therefore are referred to as 'estenotopic species' that is, of limited occurrence. The other two species, Tedania ignis and Haliclona sp., were absent in the 


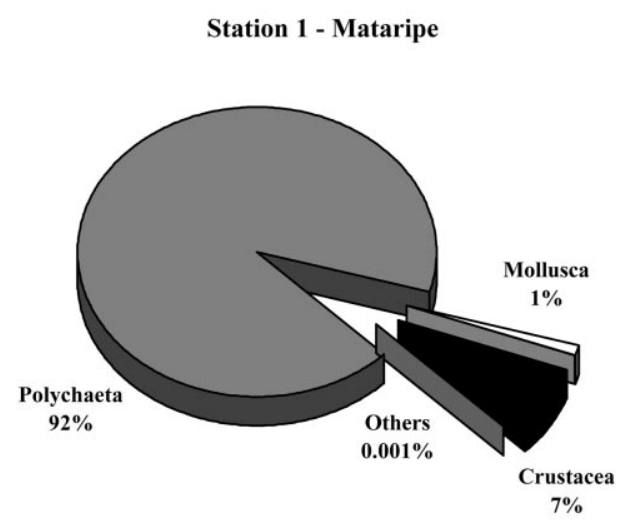

Station 3 - Pati

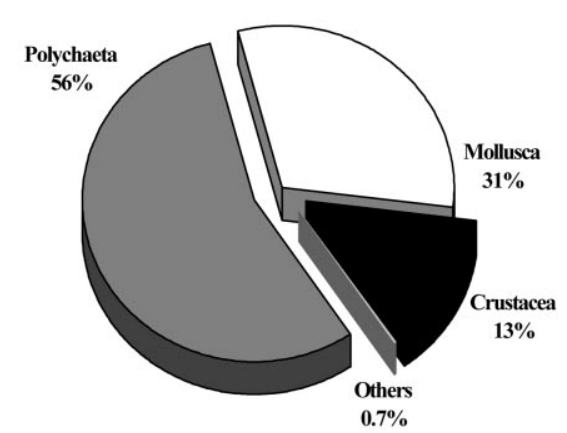

Station 2 - Madre de Deus.

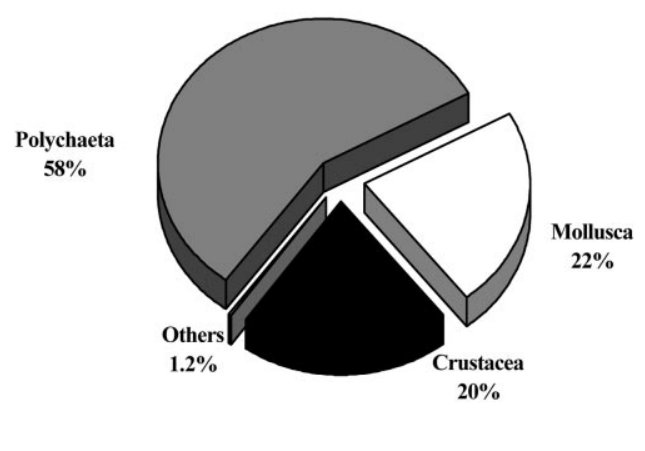

Station 4 - Illha das Fontes

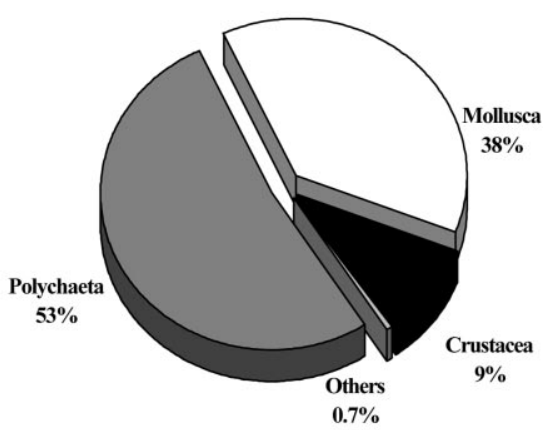

Station 5 - Jiribatuba

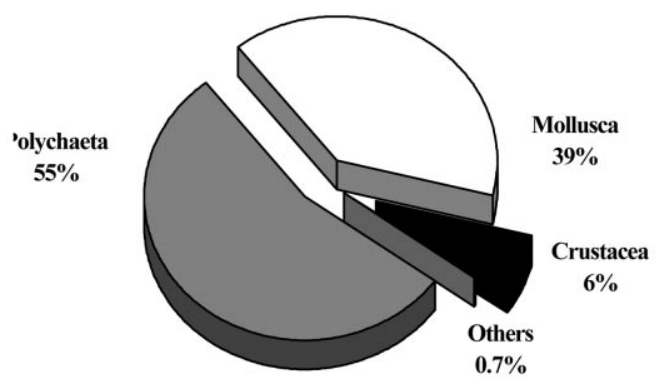

Fig. 3. Distribution of the relative abundance of the zoobenthic groups at the sampling stations at the Todos os Santos Bay.

three meso-littoral zones of the refinery (Station 1) indicating the probable presence of an inhibiting factor; nevertheless, their distribution was still shown to be 'euritopic', or common, at all other stations. In the case of Laxosuberites spp. and Halichondria sp. a certain resistance to the environmental conditions of the refinery was shown. Sponges, in general, show very specific characteristics due to their level of cellular organisation. Their sessile behaviour, their high capacity to absorb nutritional elements from the surrounding water and the fact that they suffer limited predation by other animals give them a capacity for quick and 
Table 2

Preferential species (TWINSPAN - 1st division) by sampling station and occurrence in the qualitative samples (40) per meso-littoral zone. Todos os Santos Bay, February 1994-December 1995

\begin{tabular}{|c|c|c|c|c|c|c|}
\hline \multirow[t]{3}{*}{ Species } & \multicolumn{6}{|c|}{ Sampling stations } \\
\hline & \multicolumn{2}{|c|}{ Upper meso-littoral } & \multicolumn{2}{|c|}{ Middle meso-littoral } & \multicolumn{2}{|c|}{ Lower meso-littoral } \\
\hline & $1(8)$ & $2,3,4,5(32)$ & $1(8)$ & $2,3,4,5(32)$ & $1(4)$ & $1,2,3,4,5(32)$ \\
\hline \multicolumn{7}{|l|}{ Porifera } \\
\hline Laxosuberites sp. 1 & 100 & 0 & 50 & 0 & 0 & 0 \\
\hline Laxosuberites sp. 2 & 75 & 0 & 50 & 0 & 0 & 0 \\
\hline Tedania ignis & 0 & 78 & 0 & 81 & 0 & 0 \\
\hline Haliclona sp. & 0 & 75 & 0 & 50 & 0 & 0 \\
\hline Halichondria sp. & 75 & 0 & 0 & 0 & 0 & 0 \\
\hline \multicolumn{7}{|l|}{ Annelida } \\
\hline Capitella capitata & 100 & 9.4 & 100 & 9.4 & 100 & 39 \\
\hline Glycinde multidens & 25 & 91 & 38 & 94 & 25 & 97 \\
\hline Euclymene sp. & 0 & 75 & 0 & 56 & 0 & 0 \\
\hline Laeonereis acuta & 100 & 25 & 0 & 0 & 0 & 0 \\
\hline Scoloplos sp. & 0 & 88 & 0 & 91 & 0 & 69 \\
\hline Scolelepis squamata & 0 & 0 & 0 & 0 & 75 & 0 \\
\hline Sigambra grubii & 75 & 9.4 & 0 & 0 & 0 & 0 \\
\hline Sternaspis scutata & 0 & 84 & 0 & 69 & 0 & 0 \\
\hline \multicolumn{7}{|l|}{ Mollusca } \\
\hline Lucina pectinata & 13 & 63 & 13 & 84 & 25 & 72 \\
\hline Macoma constricta & 0 & 94 & 0 & 100 & 0 & 86 \\
\hline Tagelus plebeius & 0 & 88 & 0 & 91 & 0 & 53 \\
\hline Anomalocardia brasiliana & 0 & 0 & 25 & 97 & 0 & 72 \\
\hline Corbula lyoni & 0 & 78 & 0 & 53 & 0 & 0 \\
\hline
\end{tabular}

efficient responses to environmental aggression. However, in spite of their strong potential as bioindicators, these organisms have rarely been used in environmental monitoring programs (Alcolado, 1984; Patel et al., 1985; Alcolado and Herrera, 1987; Muricy, 1989, 1992; Peixinho and Peso-Aguiar, 1989).

The polychaetes Capitella capitata, Laeonereis acuta and Sigambra grubii, appeared as preferential species in the environmental conditions imposed on them at Station 1, while Euclymene sp., Scoloplos sp. and Sternaspis scutata appear to be totally intolerant to the environmental quality produced by the refinery, appearing as euritopics at the other stations. Scolelepis squamata was the only estenotopic species found in the environmental conditions of the UM at Station 1, while Glycinde multidens was preferential at all stations with the exception of Station 1, showing its sensitivity to that environment. The dominance of polychaetes found at the stations reminds us of their ecological importance within this ecosystem. At
Station 1, the polychaetes constituted $92 \%$ of all individual samples (Table 3). Laeonereis acuta represented $73 \%$ of the worms sampled suggesting highly opportunistic behaviour while Capitella capitata and Sigambra grubii reached 14 and $4.4 \%$, respectively. At the other stations, polychaetes constituted 52-57\% of the benthic fauna. Although intolerant of the specific environmental conditions of Station 1, Sternaspis scutata was highly successful at the other sampling stations - Station 2, 51\%; Station 3, 48\%; Station 4, 39\% and the control station, $19 \%$.

Polychaetes which feed on deposits are known to be associated with the presence of oil in the substratum. The occurrence of a large number of polychaetes, among them Capitella capitata, indicates changes in the environment as they are known to be early colonisers of ecosystems which have suffered oil pollution and for their ability to reach high densities in such circumstances (Seng et al., 1987).

Among the molluscs, the bivalves Macoma 
constricta, Tagelus plebeius and Corbula lyoni showed themselves to be 'intolerant' at Station 1, while they were euritopic and preferential at the other stations. Anomalocardia brasiliana appeared as a preferential species on the MM and UM of stations 2-5, and 'sensitive' at all levels of the meso-littoral of the refinery. Lucina pectinata, preferential at all levels of stations $2-5$, also showed itself to be sensitive at all levels of Station 1 near the refinery (Table 2).

Differentiated spatial gradients of zoobenthic diversity were obtained using Friedman's test. The Shannon-Weiner index $\left(H^{\prime}\right)$, the evenness $(J)$ and the index of the number of abundant species (1/ " $C$ " Simpson) were the best at separating the stations which presented only slight differences (ignoring Station 1, which was quite different from the others (Table 4)). The index of the richness of species $\left(\mathrm{IR}_{\text {Margalef }}\right)$ highlighted the statistical significance of Station 1 and 5 (the control station) in safeguarding individual faunistic peculiarities. However, stations 2, 3 and 4 also did not differ significantly among themselves.

Diversity indices have been well publicised as methods for evaluating the impact of effluents on communities of aquatic invertebrates (Kovalak, 1981). The Shannon-Weiner index must be used preferentially when the impact acts selectively on the species in those communities, as in the case of organic compounds. There are a number of reasons for this recommendation and its popularity. Firstly, the Shannon-Weiner index is recommended when samples of the community rather than the community as a whole are being analysed; secondly, the United States Environmental Protection Agency (USEPA) recommends it as a standard index in monitoring studies, and thirdly and most importantly, it functions quite independently of the size of the samples analysed.

Reduction in diversity and rise in dominance are considered to be responses to the negative effects of environmental stress (Warwick et al., 1990). The effects of oil contamination on the benthic communities, shown by the diversity measures in the oilfields of platform Ekofish, in the North Sea, revealed themselves to be extremely localised and the differences observed between the communities were attributed to the direct action of the petroleum industry (Warwick and Clarke, 1991). 
Table 4

Diversity indices of the zoobenthic communities sampled during the period from February 1994-December 1995. ( $S=$ species numbers, $N=$ number of individuals, $H^{\prime}=$ diversity index of Shannon-Weiner, $H_{\max }=$ diversity maximum, $J=$ evenness, $\mathrm{IR}_{\text {Margalef }}=$ index of species

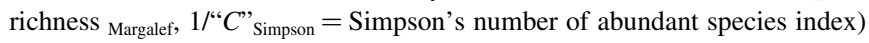

\begin{tabular}{llllllrr}
\hline Stations & $N$ & $S$ & $H^{\prime}$ & $H_{\max }$ & $J$ & $\operatorname{IR}_{\text {Margalef }}$ & $1 /$ “ $C$ ” Simpson \\
\hline 1 & 3112 & 50 & 1.401 & 3.866 & 0.359 & 6.092 & 2.27 \\
2 & 7677 & 163 & 2.989 & 5.034 & 0.589 & 18.109 & 8.41 \\
3 & 5610 & 145 & 3.030 & 4.907 & 0.611 & 16.682 & 9.27 \\
4 & 3226 & 144 & 3.317 & 4.861 & 0.673 & 17.700 & 13.63 \\
5 & 4574 & 128 & 3.104 & 4.777 & 0.643 & 15.069 & 14.50 \\
\hline
\end{tabular}

Analysis of similarity between benthic communities in the Todos os Santos Bay resulted in the identification of faunistic associations related to meso-littoral zones at each sampling station. Fig. 4 shows the quantitative grouping of the different zones based on Gower's similarity index. Analysis of the samples showed that Station 1 (F1 to F3) presented zones (Lower, Middle, and Upper) with very similar faunistic compositions due, in part, to low specimen densities and in particular, to the general lack of some of the most common species. Another tendency for grouping was based on similarities between zones of different stations in terms of density and composition. Similarities between the three zones, in both composition and density, were progressively less marked from the lower zone to the upper zone. The group consisting of the three zones of Station 1 approximated the group formed by the upper zones (F3) of the other stations suggesting that the species in the LM (F1) and MM (F2) zones of the refinery are more impacted than the upper zone (F3). In this area, there is a predominance of species with more

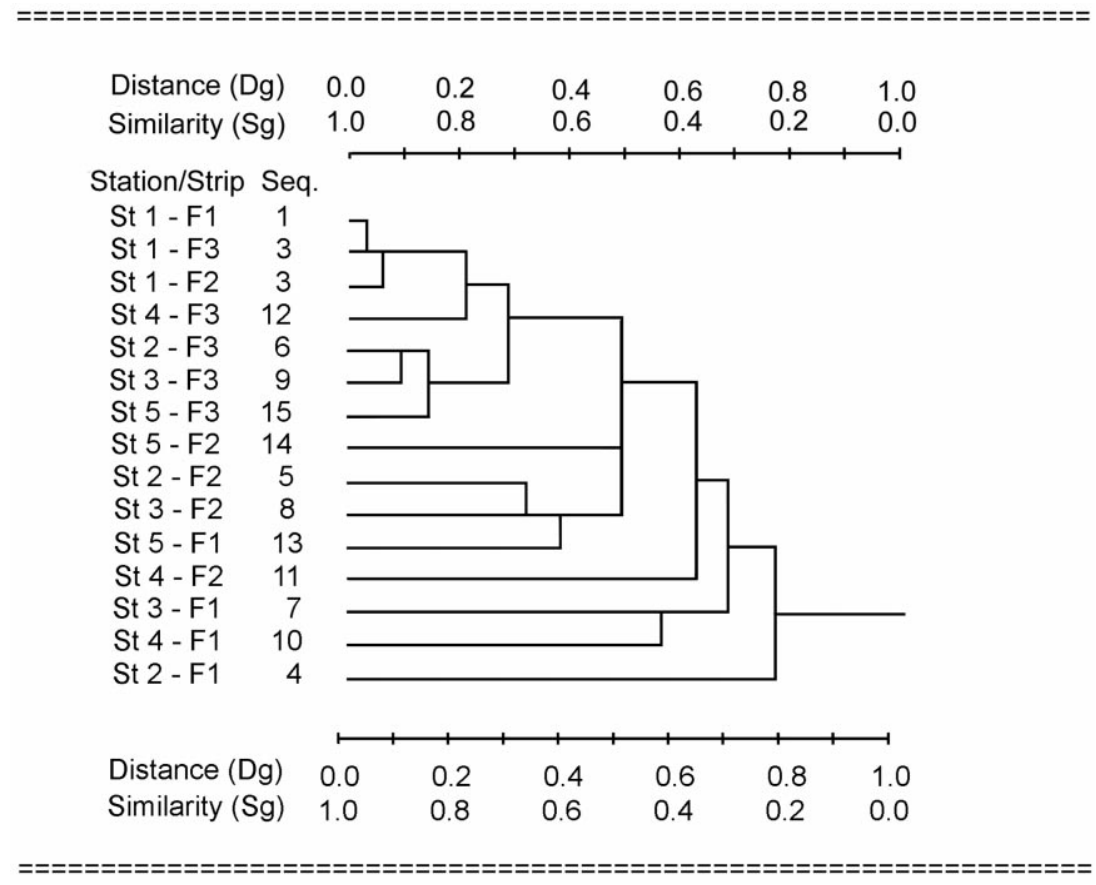

Fig. 4. Dendogram of quantitative similarities among communities of zoobenthos in three levels of meso-littoral substrate (F1-F3) at five sampling stations (S1-S5). Site relationships were calculated using Gower's general similarity coefficient (Sg) and average linkage (UPGMA). 
mobility, mainly crustaceans, which may migrate in order to avoid the excessive stress to which they are submitted. A similar grouping pattern was obtained from Jaccard's similarity matrix which is based on species presence $\mathrm{x}$ absence. The homogeneity presented in the three meso-littoral zones of the station closest to the refinery (Station 1) indicates that environmental factors were leading to the similarity of responses of local zoobenthos.

Chemical determinations of heavy metals and hydrocarbons, as well as texture composition of the sediments, made by Tavares (1996), permitted the linear correlation estimations (Pearson's $r$ ) between these and the ecological variables analysed. Significant positive relations between the density of the communities and the levels of $\mathrm{Pb}, \mathrm{Cu}, \mathrm{Cr}$ and $\mathrm{As}$ in the substratum of the UM were verified (Table 5).

Marine organisms require $\mathrm{Cu}$ in trace quantities in order to grow. In unpolluted conditions this metal is accumulated from 103 to 104 times the level present in seawater (Severy, 1923; Brooks and Rumsby, 1965). According to the USEPA (USEPA, 1972), $\mathrm{Cu}$ is accumulated by marine organisms with concentration factors of $5 \times 103$ in the soft tissues of molluscs, and of $1 \times 103$ in the muscles of fish. Crustaceans appear to be the most adept at regulating $\mathrm{Cu}$ concentrations in their bodies and detoxification occurs by the formation of granules (GESAMP, 1974). Chromium concentrations in the water, $\geq 0.1 \mathrm{mg}^{-1}$, are considered by the USEPA as threats to the marine environment while levels lower than $0.05 \mathrm{mg}^{-1}$ present minimal risks. However, smaller aquatic organisms are very sensitive to $\mathrm{Cr}$, and it can be eventually bioaccumulated to the higher levels of the trophic web (USEPA, 1972).

Arsenic occurs naturally in sea water in concentrations in the order of $2 \mathrm{mg}^{-1}$ and is virtually a nontoxic element for the organisms. Most of the data on toxicity refers to As as being from 1 to $10 \mathrm{mg}^{-1}$, in a large variety of marine species (GESAMP, 1974).

Lead contributes no nutritional or beneficial effects to the aquatic biota (Boldrini and Pereira, 1987). Once accumulated in animal tissues, $\mathrm{Pb}$ is excreted very slowly, acting as an enzymatic inhibitor, damaging cellular metabolism. Marine organisms, suffer damage to the surface of the gills inhibiting the transfer of oxygen and carbon dioxide (GESAMP, 1974). It was not possible to establish a dependence relation between density and metals cited which could justify the estimated level of correlation. Tavares (1996) indicates an enrichment of heavy metals, in particular of $\mathrm{Cr}$ and $\mathrm{As}$, in the north of the Todos os Santos Bay, but these concentrations are not yet characteristic of an acute case of contamination by these metals.

Correlation between Cd levels revealed significant negative correlation with diversity $\left(H^{\prime}\right)$ and evenness $(J)$ registered at the stations. Cd is not only not beneficial and/or non-essential for life, it is known to be highly toxic. Its excretion is insignificant once ingested, possibly leading to mutagenic and teratogenic effects (USEPA, 1976). It occurs naturally in association with $\mathrm{Zn}$ and $\mathrm{Pb}$, but its level of abundance in the earth's crust is low and the principal means of entry into the marine environment is via industrial effluents (GESAMP, 1974). Significant negative correlations between $\mathrm{Cd}$ levels in sediments and diversity, and evenness at the stations, show the possible selective effects of the presence of this metal on the biodiversity of the invertebrates in the study area.

The presence of hydrocarbons in the marine environment originate from natural and/or artificial sources. In the Todos os Santos Bay, accidental operational spills of oil and its derivatives occur as a result of the refining, production, and transportation activities of PETROBRAS. The quantities of crude oil and other contaminants that enter the environment during routine operations have persistently exposed the biota in the region to chronic levels of these contaminants over the years (Peso-Aguiar, 1996; Peso-Aguiar and Verani, 1998a,b; Peso-Aguiar et al., 1998). This chronic contamination, where the inputs to the natural environment are continuous and frequent, results in the persistent exposure of the aquatic biota (Menzies et al., 1979).

Significant negative correlations were found between ecological variables of the communities and levels of hydrocarbons, $n$-alkanes and UCM in the sediments (Table 5). According to Sharp (1979), the cumulative effects of small discharges or disturbances in the natural ecosystem provoked by the oil are difficult to detect and measure. However, these effects can be defined as resulting from exposure to sub-lethal concentrations and appear with a progressive increment in the changes to the biota. It is also 


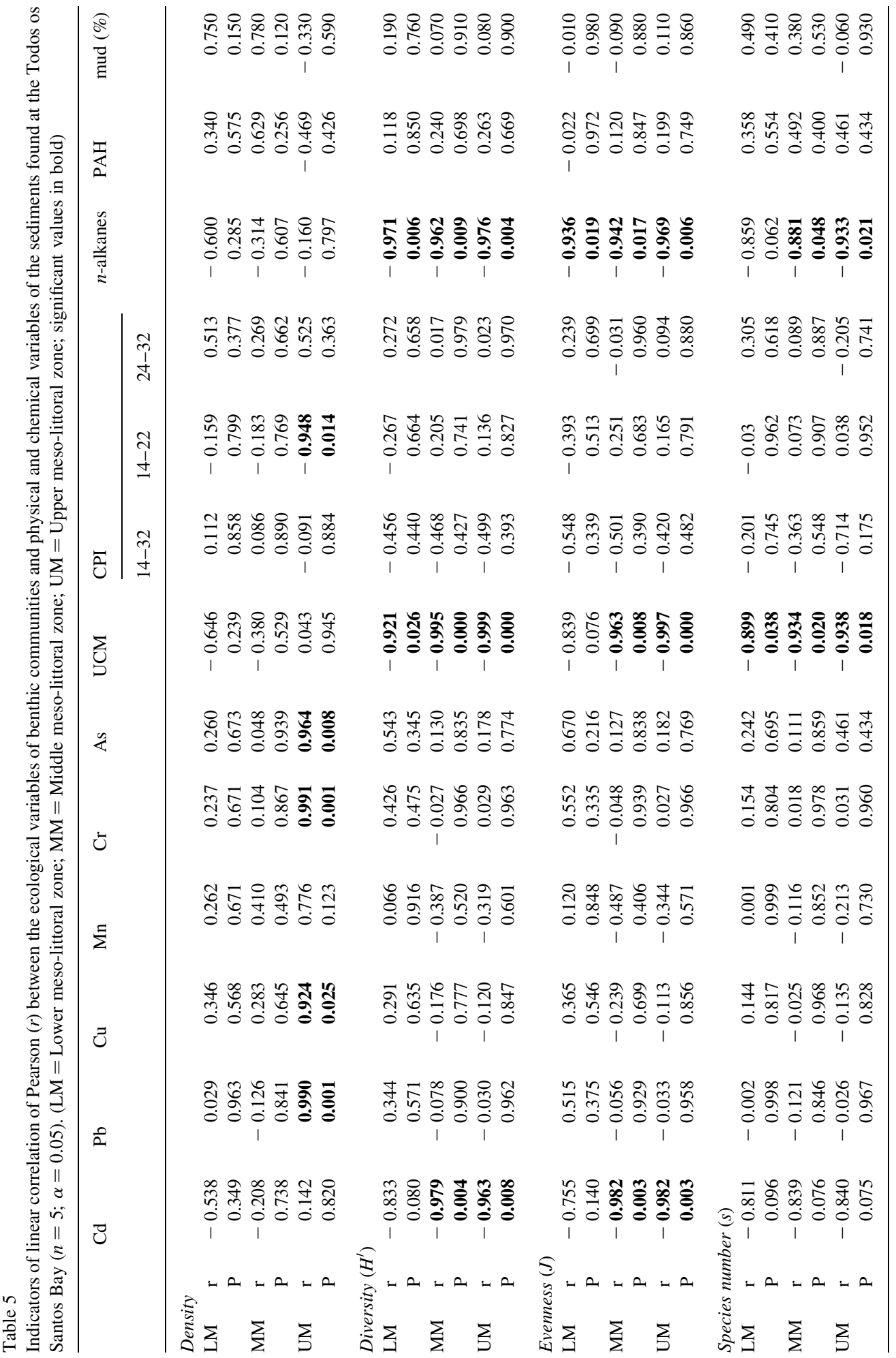


recognised that many species exhibit resistance, adaptability or resilience, masking or delaying the small changes acquired for a certain time. Seng et al. (1987) found an inverse relation between levels of hydrocarbons and density and number of species in different locations under the influence of petroleum-based activities. Environmental changes brought on by measurable alterations to the structure of the communities suggest a causal relation between rates of estimated environmental toxicity and levels of hydrocarbons in the ecosystem.

Establishing a cause and effect relation through the determination of indices for the various levels of biological organisation of the aquatic biota becomes complicated when toxicity is caused by various types of pollutants. Since pollution effects originating from a single source are rare, it becomes difficult to differentiate between changes in communities that originate from natural causes or anthropogenic effects. Independent of the origin of environmental stress, the reduction in diversity and/or the alterations in the dominance within populations are considered to be negative responses to environmental conditions. Despite the fact that the presence of hydrocarbons appears to represent the principal determining cause of the structure of the benthic communities in the Todos os Santos Bay, the toxic effects of heavy metals cannot be neglected because of their important effects on the structure of the communities analysed. The ecological approaches to the evaluation of the benthic communities submitted to the influence of multiple industrial activities undertaken by PETROBRAS to the north of the Todos os Santos Bay indicate a spatial gradient of differentiated intensity of adverse environmental conditions. Station 1, where the oil refining activities are concentrated, was the one which showed, in general, the most severe conditions for benthic marine life in the Bay.

\section{Conclusions}

The decreasing gradient of density (individuals per $\mathrm{m}^{2}$ ) at the sampling stations does not imply a statistically significant difference between the stations under the influence of PETROBRAS and the control station.

The dominant zoobenthic group at all stations,
Polychaeta, represents $92 \%$ of all the fauna sampled in the station closest to the refinery.

The sponges Tedania ignis and Haliclona sp., the polychaetes Euclymene sp., Scoloplos sp. and Sternaspis scutata and the bivalves Macoma constricta, Tagelus plebeius and Corbula lyoni are intolerant to the conditions imposed on the environment by the refinery, while the sponges Laxosuberites spp. and Halichondria sp. and the polychaete Scolelepis squamata appear resistant and the stenotopic worms Capitella capitata and Leonereis acuta appear as preferential species.

Comparative analysis of the diversity indicator parameters of the stations shows spatial gradients of the estimated values, in which the community of Station 1 features lower and statistically differentiated values in relation to the communities of the other sampling stations.

The qualitative and quantitative similarity of the fauna in the different strips of the meso-littoral is higher at Station 1, which implies that the homogeneity of its zoobenthic communities is induced by the environmental factors prevailing in the region.

Ecological indicators of the benthic communities show significant negative correlations with the presence of chemical contaminants, such as $\mathrm{Cd}$, hydrocarbons, $n$-alkanes and UCM in the sediments of the meso-littoral.

The statistical integration of the ecological indicators of the benthic communities in the areas under the influence of the oil extracting and trading activities in the Todos os Santos Bay results in a significant gradient of the effects, in the following order: Madre de Deus $(2)<$ Pati $(3)<$ Jiribatuba $(5)<$ Fontes (4) $<$ Mataripe (1) which characterises the oil refining activity as the one having the highest stressful potential over the aquatic biota of the meso-littoral.

\section{Acknowledgements}

The authors thank PETROBRAS, Petróleo do Brasil, SA for the financial support given to this study through the contract signed with the Universidade Federal da Bahia (nos. 220.2.045.93-5 and 220.2.051.94-8) and Dr Iracema Andrade Nascimento for her helpful criticisms and text revision. 


\section{References}

Alcolado, P.M., 1984. Utilidad de algunos indices ecologicos estructurales en el estudio de comunidades marinas de Cuba. Cienc. Biol. 11, 61-77.

Alcolado, P.M., Herrera, A., 1987. Efectos de la contaminación sobre las comunidades de esponjas en el litoral de la Habana. Cuba Rep. Inv. Inst. Ocean. Acad. Cienc. Cuba 68, 1-17.

Boldrini, C.V., Pereira, D.N., 1987. Metais pesados na Baía de Santos e estuários de Santos e São Vicente. Bioacumulação. Ambiente. 1 (3), 118-127.

Brooks, R.R., Rumsby, M.G., 1965. The biogeochemistry of trace element uptake by some New Zealand bivalves. Limnol. Oceanogr. 10, 521-527.

Conover, W.J., 1971. Practical Nonparametric Statistics. Wiley, New York.

Digby, P.G.N., Kempton, R.A., 1987. Multivariate Analysis of Ecological Communities. Chapman and Hall, New York.

Friedman, M., 1937. The use of ranks to avoid the assumption of normality implicit in the analysis of variance. J. Am. Stat. Assoc. 32, 675-701.

GESAMP (Joint Group of Experts on the Scientific Aspects of Marine Pollution), 1974. Review of harmful substances. Supplement to the Report of the Sixth Session 6 (10) (Suppl. 1). 1-25.

Goldberg, E.D. (Convenor), 1972. Baseline studies of heavy metal, halogenated hydrocarbon and petroleum hydrocarbon pollutants in the marine environment and research recommendations. Deliberations of the International Decade of Ocean Exploration (IDOE). Baseline Conference, May 24-26.

Hill, M.O., 1979. TWINSPAN — a FORTRAN program for arranging multivariate data in an ordered two-way table by classification of the individuals and attributes. Ecology and Systematics. Cornell University, Ithaca, New York.

Kovalak, W.P., 1981. Assessment and prediction of impacts of effluents on communities of benthic stream macroinvertebrates. In: Bates, J.M., Weber, C.I. (Eds.). Ecological Assessments of Effluent Impacts on Communities of Indigenous Aquatic Organisms, ASTM STP 730. American Society for Testing and Materials, Washington DC, pp. 255-263.

Menzies, R.J., Morgan, J.P., Oppenheimer, C.H., El-Sayed, S.Z., Sharp, J.M., 1979. Design of the offshore ecology investigation. The Offshore Ecology Investigation, Rice University Studies 65 (4/5), 19-32.

Muricy, G., 1989. Sponges as pollution-biomonitors at Arraial do Cabo, southeastern Brazil. Rev. Bras. Biol. 49 (2), 347-354.

Muricy, G., 1992. Structure des peuplements des spongiaires autour de l'égout de Cortiou (Marseille, France). Vie et Milieu 41 (4), 205-221.

Patel, B., Balani, M.C., Patel, S., 1985. Sponges 'sentinel' of heavy metal. Sci. Total Environ. NLD 41 (2), 143-152.

Peso-Aguiar, M.C. (Coordenação), 1996. Projeto 4. Comunidades Bentônicas, vol. 1. Tomo VI. Programa de Monitoramento dos Ecossistemas ao Norte da Baía de Todos os Santos, Relatório Técnico Final. Convênio UFBA/PETROBRAS nos. 220.2.045.93-5 e 220.2.051.94-8, Salvador, Bahia, Brasil.
Peso-Aguiar, M.C., Verani, J.R., 1998a. Macoma constricta (Bruguière, 1792) (Bivalvia,Tellinidae) as Biomonitor of the Chronic Environmental Contamination by Petroleum in Todos os Santos Bay (Salvador, Bahia, Brazil), vol. 26. Schweizerbart'sche Verlagsbuchhandlung, Stuttgart (pp. 2015-2018).

Peso-Aguiar, M.C., Verani, J.R., 1998. índices biométricos da agressão ambiental do petróleo e seus derivados em Macoma constricta (Bivalvia, Tellinidae). Anais do VIII Seminário Regional de Ecologia, São Carlos, SP, vol. 8, pp. 1447-1492.

Peso-Aguiar, M.C., Verani, J.R., Rocha, O., 1998. Estimativa da produção anual da biomassa de Macoma constricta (Bivalvia, Tellinidae) na Baía de Todos os Santos, BA. Anais do VIII Seminário Regional de Ecologia, São Carlos, SP, vol. 8, pp. 1497-1510.

Peixinho, S., Peso-Aguiar, M.C., 1989. Marine sponges as biomonitors: an ecological approach at Todos os Santos Bay, Bahia, Brazil. Proceedings of the International Workshop on Biomonitors, Bahia, Brazil, December 4-9. MARC (Monitoring and Assessment Research Center, King's College, London)/UFBA (Universidade Federal da Bahia).

Seng, L.T., Kwong, L.Y., Chye, H.S., Huat, K.K., Pheng, K.S., Hanapi, S., Meng, W.T., Legore, R.S., Ligny, W., Tan, G.T., 1987. Effects of a crude oil terminal on tropical benthic communities in Brunei. Mar. Pollut. Bull. 18 (1), 31-35.

Severy, H., 1923. The occurrence of copper and zinc in certain marine animals. J. Biol. Chem. 55, 79-82.

Sharp, J.M., 1979. The cumulative effects of petroleum drilling and production in coastal and near-shore areas. The Offshore Ecology Investigation, Rice University Studies 65 (4/5), 3-15.

Smith, R.W., Bernstein, B.B., Cimberg, R.L., 1987. Community environmental relationships in the benthos: applications of multivariate analytical techniques. In: Soule, D.F., Kleppel, G.S. (Eds.). Marine Organisms as Indicators. Springer, New York, pp. 247-326.

Sneath, P.H.A., Sokal, R.R., 1973. Numerical Taxonomy. Freeman, San Francisco.

Tavares, T. (Coordenação), 1996. Projeto 8. Química Ambiental, vol.1. Distribuição Espacial de Metais Pesados e Hidrocarbonetos ao Norte da Baía de Todos os Santos. Programa de Monitoramento dos Ecossistemas ao Norte da Baía de Todos os Santos, Relatório Técnico Final. Convênio UFBA/PETROBRAS nos. 220.2.045.93-5 e 220.2.051.94-8, Salvador, Bahia, Brasil.

USEPA (Environmental Protection Agency), 1972. Water Quality Criteria, Ecological Research Series. USEPA, Washington DC.

USEPA (Environmental Protection Agency), 1976. Quality Criteria for Water. USEPA, Washington DC.

Warwick, R.M., Platt, H.M., Clarke, K.R., Agard, J., Gobin, J., 1990. Analysis of macrobenthics and meiobenthics community structure in relation to pollution and disturbance in Hamilton Harbour, Bermuda. J. Exp. Mar. Biol. Ecol. 138, 119-142.

Warwick, R.M., Clarke, K.R., 1991. A comparison of some methods for analysing changes in benthic community structure. J. Mar. Biol. Assoc. UK 71, 225-244. 